\title{
ANALISIS PENGETAHUAN METAKOGNITIF DAN KESADARAN METAKOGNITIF PESERTA DIDIK SERTA HUBUNGANNYA DENGAN PRESTASI BELAJARNYA
}

\author{
Parlan $^{1 *}$, Nur Aini Indri Astutik ${ }^{1}$, Muhammad Su'aidy ${ }^{1}$ \\ 1 Jurusan Kimia FMIPA Universitas Negeri Malang, Jl. Semarang No. 5 Malang
}

\begin{abstract}
Abstrak - Penelitian ini bertujuan untuk menganalisis pengetahuan metakognitif (pengetahuan deklaratif, prosedural, dan kondisional) dan kesadaran metakognitif peserta didik dan hubungannya dengan hasil belajarnya pada materi larutan penyangga. Desain penelitian yang digunakan adalah penelitian deskriptif. Instrumen yang digunakan berupa 12 butir soal pilihan ganda (multiple choice) pada materi larutan penyangga, disertai tiga pertanyaan pengetahuan metakognitif dan angket MAI (Metacognitive Awareness Inventory). Penskoran kualitas pengetahuan metakognitif dilakukan dengan rubrik yang dikembangkan oleh Rompayom (2010). Hasil penelitian menunjukkan bahwa: 1) mayoritas pengetahuan deklaratif dan pengetahuan prosedural peserta didik di tingkat sedang, 2) mayoritas pengetahuan kondisional peserta didik di tingkat rendah, 3) ada hubungan antara pengetahuan metakognitif dan hasil belajar $(\mathrm{r}=0,44)$, dan 4) tidak ada hubungan antara kesadaran metakognitif dan hasil belajar $(\mathrm{r}=-0,13)$. Skor pengetahuan metakognitif peserta didik merupakan prediktor hasil belajar yang lebih baik daripada skor kesadaran metakognitif peserta didik. Dalam pembelajaran kimia dengan karakteristik materi seperti larutan penyangga, maka guru perlu memperhatikan pengetahuan metakognitif peserta didik untuk memperoleh hasil pembelajaran yang lebih baik.
\end{abstract}

Kata-kata kunci: analisis; pengetahuan metakognitif; kesadaran metakognitif; larutan penyangga.

\begin{abstract}
This study aimed to examine students' metacognitive knowledge (i.e., declarative, procedural, and conditional knowledge) and the metacognitive awareness and their relationship with the learning achievements on buffer solution material. A descriptive research was used in this research. The instruments used were in the form of 12 multiple choice test of buffer solution, accompanied by three questions of metacognitive knowledge and Metacognitive Awareness Inventory (MAI). The scoring of students' metacognitive knowledge quality was done with a rubric developed by Rompayom (2010). The results showed that: 1) the majority of students' declarative and procedural knowledge at a moderate level, 2) the majority of students' conditional knowledge at low levels, 3) there was a significant relationship between metacognitive knowledge and learning achievements $(r=0.44)$, and 4) there was no relationship between metacognitive awareness and learning achievements $(r=-0.13)$. The scores of students' metacognitive knowledge are a better predictor of learning achievements than students' metacognitive awareness scores. In learning chemistry with material characteristics such as buffer solutions, the teacher needs to pay attention to the students' metacognitive knowledge to get better learning achievements.
\end{abstract}

Keywords: analysis; metacognitive knowledge; metacognitive awareness; buffer solution.

\footnotetext{
${ }^{*}$ Corresponding author: Jurusan Kimia, Universitas Negeri Malang, Malang 65145, Indonesia. Email: parlan.fmipa@,um.ac.id
} 


\section{PENDAHULUAN}

Guru kimia sebagai pendidik berkewajiban menyusun rancangan pembelajaran yang sesuai dengan dengan karakteristik materi dan peserta didik, agar peserta didik dapat memahami kimia dengan mudah (Sirhan, 2017). Hasil-hasil penelitian menunjukkan bahwa masih banyak peserta didik beranggapan bahwa kimia merupakan pelajaran yang sulit dan membosankan. Faktor-faktor yang menyebabkan peserta didik mengalami kesulitan dalam belajar kimia, di antaranya adalah situasi belajar yang kurang menyenangkan, media pembelajaran yang tidak sesuai, maupun kurangnya motivasi belajar peserta didik. Faktor-faktor terebut dapat mengarahkan peserta didik pada miskonsepsi terhadap konsep-konsep kimia yang dipelajari (Sirhan, 2007).

Hasil penelitian Sesen (2011) menunjukkan bahwa masih terdapat miskonsepsi pada beberapa materi kimia, termasuk materi larutan penyangga. Marsita (2010) melakukan penelitian tentang kesulitan peserta didik dalam mempelajari larutan penyangga. Hasilnya, sebanyak 35,52\% peserta didik mengalami kesulitan membedakan larutan penyangga asam dan larutan penyangga basa. Peserta didik juga mengalami kesulitan menentukan pasangan asam basa konjugasi, 26,03\% peserta didik kesulitan menghitung $\mathrm{pH}$ larutan penyangga, 40,83\% peserta didik kesulitan mengerjakan soal tentang aplikasi larutan penyangga dalam tubuh makhluk hidup.

Cook, Kennedy, \& McGuire (2013) menyatakan bahwa tingginya potensi peserta didik yang mengalami kesulitan dalam memahami materi larutan penyangga, disebabkan karena adanya anggapan bahwa banyak materi tersebut berisi fakta dan rumus-rumus yang harus diingat dibandingkan dengan pemahaman konsep dan pemecahan masalah. Hasil analisis yang dilakukan penulis terhadap beberapa buku ajar (paket) Kimia SMA menunjukkan sekitar 60\% soal latihan yang ada merupakan soal hitungan yang mengutamakan hafalan rumus, dan sekitar $20 \%$ soal berisi tentang peran larutan penyangga yang mengutamakan hafalan.

Sebelum membelajarkan peserta didiknya, guru perlu mempersiapkan mental peserta didik agar dapat mengikuti pembelajaran dengan baik. Guru juga perlu memfasilitasi peserta didik untuk menggali pengetahuan awal peserta didik sebelum pembelajaran agar pembelajaran yang dialami peserta didik merupakan pembelajaran yang bermakna. Tahapan ini dapat disebut sebagai tahap pengukuran pengetahuan metakognitif peserta didik. Pada tahapan ini, tingkat pemahaman atau pengetahuan awal peserta didik terhadap materi dapat diketahui (Egan, 2014). Pengetahuan awal yang dimiliki peserta didik, dapat membantu atau sebaliknya menghalangi proses pembelajaran. Pengetahuan yang akurat dapat menjadi pondasi, sedangkan pengetahuan yang tidak tepat dapat mengarah pada miskonsepsi (Amborse, 2010).

Salah satu komponen metakognisi adalah pengetahuan metakognitif. Flavell (1979) percaya bahwa mengidentifikasi pengetahuan metakognitif peserta didik dapat membantu guru mengetahui dimana kesulitan belajar mereka. Bagaimana peserta didik menentukan tujuan belajar, memilih strategi, dan mengevaluasi cara belajar memberikan gambaran mengenai kemampuan metakognitifnya. Informasi mengenai pengetahuan metakogntif peserta didik bermanfaat untuk memperoleh penjelasan mengapa peserta didik kurang bisa memahami materi kimia dengan baik.

Pengetahuan metakognitif dibagi ke dalam tiga aspek, yaitu pertama adalah pengetahuan deklaratif, yang merupakan segala pengetahuan yang dimiliki peserta didik tentang penyelesaian tugas. Kedua adalah pengetahuan prosedural, yaitu pengetahuan tentang bagaimana menyelesaikan tugas yang berkaitan dengan pemilihan strategi dan proses pemecahan masalah dari awal hingga akhir. Ketiga adalah pengetahuan kondisional yang merupakan pengetahuan yang berkaitan dengan kapan dan mengapa menggunakan pengetahuan deklaratif dan prosedural untuk menyelesaikan masalah yang diberikan (Rompayom et al., 2010). Ketiga bagian pengetahuan metakognitif tersebut membantu peserta didik berfikir, membantu dalam belajar, bagaimana belajar dengan baik untuk mendapatkan hasil yang maksimal tentang apa saja yang telah dipelajari selama pembelajaran berlangsung. Hal tersebut menunjukkan bagaimana peserta didik dapat mengatur dan mengoperasikan memori yang dimilikinya (Jaleel, 2016). Penelitian ini berupaya menggali pengetahuan metakognitif peserta didik 
yang terkait dengan pemahamannya tentang larutan penyangga dan hubungannya dengan prestasi belajarnya (Josep, 2008), Pengetahuan metakognitif merupakan aspek penting dalam pembelajaran. Dengan mengetahui kualitas pengetahuan metakognitif peserta didik dapat digunakan sebagai bahan pertimbangan dalam memilih strategi pembelajaran yang sesuai dengan karakteristik peserta didik dan materi yang akan dibelajarkannya.

Penelitian tentang pemahaman, kesulitan, dan miskonsepsi dalam pembelajaran larutan penyangga telah banyak dilakukan ((Isnaini, Masriani, \& Santika, 2015); (Ulva, Santosa, \& Parlan, 2016); dan (Parastuti, Suharti, Ibnu, 2016)), tetapi penelitian yang berupaya menggali pengetahuan metakognitif peserta didik dan hubungannya dengan variabel-variabel pembelajaran larutan penyangga belum dilakukan.

\section{METODE}

Penelitian ini merupakan penelitian deskriptif dengan metode survei. Hasil penelitian dijabarkan secara deskriptif untuk masing-masing kategori yaitu pengetahuan deklaratif, pengetahuan prosedural, dan pengetahuan kondisional serta dilakukan uji korelasi antara pengetahuan metakognitif dengan prestasi belajar dan MAI (metacognitive awareness inventory) peserta didik. Penelitian dilakukan di salah satu SMA Negeri di Kabupaten Blitar. Di sekolah tersebut terdapat dua kelas XI MIPA, yaitu XI MIPA 1 dan XI MIPA 2. Kedua kelas memiliki kemampuan yang setara. Pemilihan kelas sebagai subjek penelitian dilakukan dengan cara random. Kelas XI MIPA 2 digunakan sebagai subjek uji coba soal, dan kelas XI MIPA 1 digunakan sebagai subjek penelitian. Kepada peserta didik kelas XI MIPA 1 diberikan 12 soal pilihan ganda (6 soal katagori sukar, 3 soal katagori sedang, dan 2 soal katagori mudah) untuk mengukur prestasi belajarnya dan diikuti dengan tiga pertanyaan terbuka untuk mengukur pengetahuan metakognitifnya. Pedoman penskoran jawaban peserta didik tentang pengetahuan metakognitif mengacu pada rubrik yang dikembangkan oleh Rompayom (2010) seperti disajikan pada Tabel 1. Penskoran jawaban peserta didik tentang pengetahuan metakognitifnya dilakukan oleh dua orang penilai (rater). Hasil analisis terhadap kesetaraan kedua penilai diperoleh nilai kappa (inter-rater reliability) sebesar 0,936 ( $<<0,05)$.

Tabel 1. Pedoman Penskoran Pengetahuan Metakognitif

\begin{tabular}{|c|c|c|c|}
\hline \multirow{2}{*}{ Skor } & \multicolumn{3}{|c|}{ Deskripsi } \\
\hline & Pengetahuan Deklaratif & Pengetahuan Prosedural & Pengetahuan Kondisional \\
\hline 0 & $\begin{array}{l}\text { Tidak ada yang } \\
\text { berhubungan dengan tugas } \\
\text { (soal). Peserta didik tidak } \\
\text { dapat mendeskripsikan } \\
\text { berhubungan dengan apa } \\
\text { tugas yang diberikan. }\end{array}$ & $\begin{array}{l}\text { Peserta didik tidak } \\
\text { mendeskripsikan strategi yang } \\
\text { digunakan untuk menyelesaikan } \\
\text { masalah, dan bagaimana peserta } \\
\text { didik menyelesaikan masalah. }\end{array}$ & $\begin{array}{l}\text { Peserta didik tidak } \\
\text { menjelaskan kapan dan } \\
\text { mengapa menggunakan } \\
\text { strategi tersebut untuk } \\
\text { menyelesaikan masalah. }\end{array}$ \\
\hline 1 & $\begin{array}{l}\text { Peserta didik menuliskan } \\
\text { gagasan secara tidak } \\
\text { spesifik. Gagasan } \\
\text { berhubungan dengan kimia, } \\
\text { tetapi tidak berhubungan } \\
\text { dengan pertanyaan. }\end{array}$ & $\begin{array}{l}\text { Peserta didik nampak memahami } \\
\text { maksud tugas, tetapi peserta didik } \\
\text { membuat gagasan yang tidak } \\
\text { spesifik dan tidak berhubungan } \\
\text { dengan informasi yang diberikan } \\
\text { atau pertanyaan yang diajukan. }\end{array}$ & $\begin{array}{l}\text { Peserta didik menjabarkan } \\
\text { (memberikan daftar) strategi } \\
\text { secara umum untuk } \\
\text { menyelesaikan masalah, } \\
\text { tetapi peserta didik tidak } \\
\text { menjelaskan kapan dan } \\
\text { mengapa strategi tersebut } \\
\text { digunakan. }\end{array}$ \\
\hline
\end{tabular}


Lanjutan tabel...

$\begin{array}{llll}2 & \text { Peserta didik memiliki } & \text { Peserta didik dengan jelas } & \text { Peserta didik memaparkan } \\ \text { pandangan yang jelas } & \text { menjelaskan strategi mana yang } & \text { dengan jelas kapan dan } \\ \text { tentang apa yang } & \text { peserta didik gunakan. Peserta } & \text { mengapa menggunakan } \\ \text { berhubungan dengan tugas } & \text { didik secara eksplisit menentukan } & \text { strategi untuk menyelesaikan } \\ & \text { implikasi antara informasi yang } & \text { masalah. Overview dari } \\ & \text { diberikan dengan pertanyaan } & \text { strategi yang berhubungan } \\ & & \text { dengan hal konkrit dalam } \\ & \text { memberikan informasi dan } \\ & \text { jawaban. }\end{array}$

Instrumen prestasi belajar yang digunakan dalam penelitian ini adalah tes tertulis yang terdiri dari 12 butir soal pilihan ganda disertai tes pengetahuan metakognitif (validitas isi menurut ahli sebesar 94\% dan reliabilitas sebesar 0,682) dan angket MAI (metacognitive awareness inventory, Schraw \& Dennison: 1994). Dalam angket MAI terdapat 52 butir pertanyataan dengan permintaan jawaban ya atau tidak. Jika jawaban ya diberi skor 1 dan jika jawaban tidak diberi skor 0. Dalam penelitian ini pengetahuan metakognitif peserta didik diukur dengan menggunakan dua jenis instrumen, yaitu instrumen tes yang diadaptasi dari Rompayom (2010) dan angket MAI (Schraw \& Dennison, 1994).

Jenis analisis hubungan dua variabel yang dilakukan disesuaikan jenis-jenis data yang diperoleh. Rangkuman analisis yang dilakukan disajikan dalam Tabel 2.

Tabel 2. Teknik Statistika yang Digunakan

\begin{tabular}{ccc}
\hline Variabel 1 & Variabel 2 & Teknik Statistik Korelasi \\
(Jenis Skala Data) & (Jenis Skala Data) & Biserial \\
\hline Hasil Belajar & Pengetahuan Metakognitif & \\
(Interval, Kontinum) & (Ordinal, Kontinum) & Point Biserial \\
Hasil Belajar & MAI & \\
(Interval, Kontinum) & (Nominal, Diskrit) & \\
\hline
\end{tabular}

Kriteria yang digunakan untuk menyatakan kualitas hubungan di antara dua variabel disajikan pada Tabel 3.

Tabel 3. Makna Nilai Korelasi (r) Product Moment

\begin{tabular}{|c|c|}
\hline $\mathrm{R}$ & Makna \\
\hline $0,00-0,19$ & Sangat rendah/sangat lemah \\
\hline $0,20-0,39$ & Rendah/lemah \\
\hline $0,40-0,59$ & Sedang \\
\hline $0,60-0,79$ & Tinggi/kuat \\
\hline $0,80-1,00$ & Sangat tinggi/sangat kuat \\
\hline
\end{tabular}

\section{HASIL DAN PEMBAHASAN}

Data penelitian pengetahuan metakognitif peserta didik disajikan dalam bentuk persentase jawaban hasil tes pengetahuan metakognitif beserta pembahasannya. Pembahasan tersebut meliputi pengetahuan deklaratif, pengetahuan prosedural, dan pengetahuan kondisional pada materi larutan penyangga. Data hasil penelitian juga menguraikan tentang hubungan antara hasil belajar peserta didik dengan pengetahuan metakognitif yang diukur dengan dua instrumen, yaitu instrumen yang dikembangkan Rompayom (2010) dan MAI (Schraw \& Dennison, 1994). Pembahasan juga meliputi perbandingan instrumen yang lebih mampu menggambarkan pengetahuan metakognitif peserta didik. 


\section{Pengetahuan Deklaratif}

Data pengetahuan deklaratif peserta didik pada materi larutan penyangga, diperoleh dari hasil tes pengetahuan metakognitif bagian pengetahuan deklaratif. Persentase peserta didik tiap skor dapat dilihat pada Tabel 4 .

Tabel 4. Persentase Peserta Didik Tiap Skor pada Kategori Pengetahuan Deklaratif

\begin{tabular}{|c|c|c|c|c|c|c|}
\hline \multirow{3}{*}{ No. Soal } & \multicolumn{6}{|c|}{ Skor } \\
\hline & \multicolumn{2}{|c|}{0} & \multicolumn{2}{|c|}{1} & \multicolumn{2}{|c|}{2} \\
\hline & $\sum$ & $\%$ & $\sum$ & $\%$ & $\sum$ & $\%$ \\
\hline 1 & 15 & $47 \%$ & 7 & $22 \%$ & 10 & $31 \%$ \\
\hline 2 & 12 & $38 \%$ & 19 & $59 \%$ & 1 & $3 \%$ \\
\hline 3 & 9 & $28 \%$ & 21 & $66 \%$ & 2 & $6 \%$ \\
\hline 4 & 7 & $22 \%$ & 25 & $78 \%$ & 0 & $0 \%$ \\
\hline 5 & 10 & $31 \%$ & 22 & $69 \%$ & 0 & $0 \%$ \\
\hline 6 & 5 & $16 \%$ & 27 & $84 \%$ & 0 & $0 \%$ \\
\hline 7 & 8 & $25 \%$ & 24 & $75 \%$ & 0 & $0 \%$ \\
\hline 8 & 12 & $38 \%$ & 19 & $59 \%$ & 1 & $3 \%$ \\
\hline 9 & 10 & $31 \%$ & 22 & $69 \%$ & 0 & $0 \%$ \\
\hline 10 & 10 & $31 \%$ & 22 & $69 \%$ & 0 & $0 \%$ \\
\hline 11 & 26 & $81 \%$ & 6 & $19 \%$ & 0 & $0 \%$ \\
\hline 12 & 9 & $28 \%$ & 23 & $72 \%$ & 0 & $0 \%$ \\
\hline Rata-rata & 11 & $35 \%$ & 20 & $61 \%$ & 1 & $4 \%$ \\
\hline
\end{tabular}

Pada soal terkait prinsip kerja larutan penyangga, yaitu jika ke dalam larutan penyangga ditambahkan sedikit asam kuat atau sedikit basa kuat disajikan pada soal nomor 1 dan 2 . Sebagian besar peserta didik memperoleh skor 0 pada soal nomor 1 dan skor 1 pada soal nomor 2 . Peserta didik dengan skor 1 sebagian besar menuliskan gagasan secara tidak spesifik, peserta didik hanya menyebutkan "Prinsip Kerja Larutan Penyangga" untuk soal nomor 1, dan "Pergeseran Kesetimbangan", untuk soal nomor 2. Peserta didik tidak menyinggung tentang sifat larutan maupun sifat asam basa dalam sub materi ini. Contoh jawaban peserta didik terhadap soal nomor 1 tentang prinsip kerja larutan penyangga yang memperoleh skor 2 (jawaban benar).

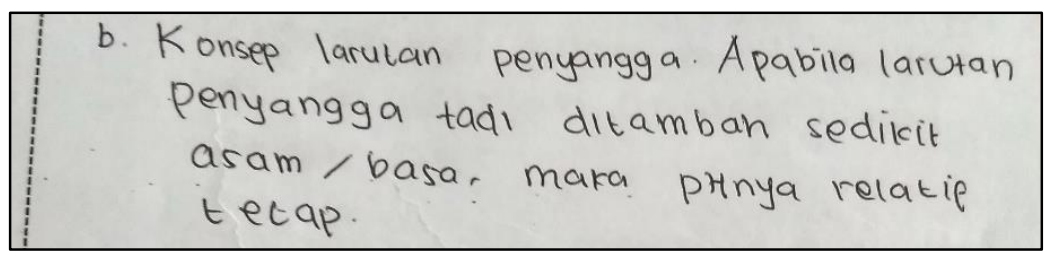

Gambar 1. Contoh jawaban peserta didik terhadap soal nomor 1

Pada soal terkait komponen penyusun larutan penyangga, sebagian besar peserta didik memperoleh skor 1. Peserta didik dengan skor 1, hanya menyebutkan "Sifat Larutan dan Menghitung $\mathrm{pH}$ ". Peserta didik menyebutkan bagaimana langkah-langkah atau cara menghitung $\mathrm{pH}$ dan tidak menyinggung tentang perhitungan mol. Berikut adalah contoh jawaban peserta didik yang memperoleh skor 1 untuk soal yang menanyakan komponen larutan penyangga.

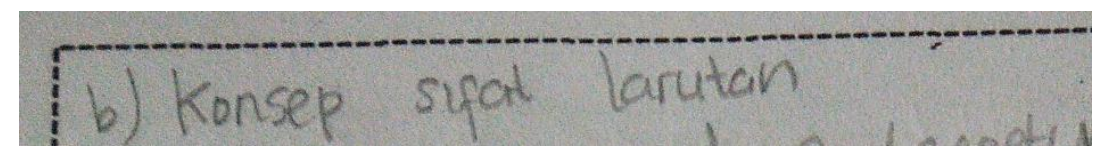

Gambar 2. Contoh jawaban peserta didik yang memperoleh skor 1

Jawaban yang diinginkan adalah peserta didik dapat mendeskripsikan larutan yang di dalamnya terdapat komponen asam lemah dan basa konjugasinya atau basa lemah dan asam konjugasinya. 
Misalnya campuran larutan yang mengandung $\mathrm{CH}_{3} \mathrm{COOH}$ (asam asetat) dan $\mathrm{CH}_{3} \mathrm{COO}^{-}$(basa konjugat dari asam asetat).

Pada soal terkait klasifikasi jenis larutan penyangga, sebagian besar peserta didik memperoleh skor 1. Peserta didik dengan skor 1, hanya menyebutkan "Jenis Larutan Penyangga" atau "Sifat Larutan Penyangga" untuk soal nomor 4, dan menyebutkan pengetahuan tentang sifat larutan penyangga tetapi kurang tepat untuk soal nomor 5. Peserta didik mencoba menggambarkan bagan pembentukan larutan penyangga asam, namun kurang tepat. Pada tanda panah pertama yang dimaksud peserta didik adalah jika mereaksikan asam lemah berlebih dengan basa kuat, maka hanya akan terbentuk garam dari asam lemah. Pada tanda panah ke dua, peserta didik mencoba menunjukkan bahwa jika mereaksikan garam dari asam lemah dengan asam lemah, maka akan membentuk larutan penyangga.

Pada soal terkait perhitungan $\mathrm{pH}$ penyangga asam, sebagian besar peserta didik memperoleh skor 1. Peserta didik dengan skor 1, hanya menyebutkan "pH larutan Penyangga" atau "pH larutan Penyangga Asam". Soal terkait perhitungan pH larutan penyangga basa, sebagian besar peserta didik memperoleh skor 1. Peserta didik dengan skor 1, hanya menyebutkan " $\mathrm{pH}$ larutan Penyangga Basa”.

Pada soal terkait $\mathrm{pH}$ larutan penyangga setelah penambahan sedikit asam kuat atau basa kuat atau dilakukan sedikit pengenceran, sebagian besar peserta didik memperoleh skor 1. Peserta didik dengan skor 1 sebagian besar menuliskan gagasan secara tidak spesifik, peserta didik hanya menyebutkan " $\mathrm{pH}$ Larutan Penyangga". Pada perhitungan $\mathrm{pH}$ larutan penyangga karena pengenceran, peserta didik belum mampu menentukan pengaruh penambahan pelarut dalam larutan penyangga.

Pada soal terkait peran larutan penyangga dalam tubuh makhluk hidup, sebagian besar peserta didik memperoleh skor 0. Peserta didik belum mampu menentukan pengetahuan yang terkait dengan pengetahuan apa, peran larutan penyangga dalam tubuh makhluk hidup. Peserta didik tidak menyebutkan persamaan reaksi, prinsip kerja larutan penyangga maupun asam basa.

Pada setiap soal yang menyangkut perhitungan $\mathrm{pH}$, jika dilihat dari pengetahuan prosedural, sebagian besar peserta didik mahir melakukan perhitungan $\mathrm{pH}$ larutan penyangga, tetapi belum mampu menjelaskan konsep dan pengetahuan terkait yang diperlukan untuk menyelesaikan perhitungan larutan penyangga, seperti persamaan reaksi dan perhitungan jumlah mol komponenkomponen larutan penyangga.

Berdasarkan uraian di atas, dapat disimpulkan bahwa mayoritas peserta didik (61\%) memiliki pengetahuan deklaratif tingkat sedang. Dengan kata lain, mayoritas peserta didik Kelas XI MIPA SMA menuliskan gagasan secara tidak spesifik. Peserta didik sudah mampu menyebutkan konsep dan pengetahuan yang terkait dengan pertanyaan yang diberikan, tetapi sebagian peserta didik belum mampu mendeskripsikannya secara lebih jelas.

Meskipun beberapa peserta didik sudah mampu menyebutkan/menghitung $\mathrm{pH}$ larutan penyangga, prinsip kerja larutan penyangga, jenis larutan penyangga, namun belum mampu menyebutkan materi prasyarat seperti asam, basa, dan perhitungan jumlah mol. Menurut Amborse (2010) setiap peserta didik pasti memiliki pengetahuan awal, pengetahuan yang peserta didik miliki ini dapat membantu atau menghalangi proses pembelajaran. Apabila peserta didik memiliki pengetahuan awal yang cukup maka mereka akan dapat memahami materi yang dipelajari dengan baik. Jika pengetahuan awal (materi prasyarat) dikuasai dengan baik, maka pengetahuan deklaratif akan semakin baik pula. 


\section{Pengetahuan Prosedural}

Data pengetahuan prosedural peserta didik pada materi larutan penyangga, diperoleh dari hasil tes pengetahuan metakognitif bagian pengetahuan prosedural. Persentase peserta didik tiap skor dapat dilihat pada Tabel 5 .

Berdasarkan persentase rata-rata perolehan skor peserta didik, sebanyak 39\% peserta didik memiliki pengetahuan prosedural rendah, $48 \%$ peserta didik memiliki pengetahuan prosedural sedang, dan 13\% peserta didik berada ditingkat tinggi. Tingkat pengetahuan prosedural sebagian besar peserta didik berada ditingkat sedang. Secara umum dapat disimpulkan bahwa peserta didik sudah mampu memahami maksud tugas, tetapi peserta didik menuliskan gagasan atau tahapan yang tidak spesifik dan tidak berhubungan dengan informasi yang diberikan dan pertanyaan yang diajukan.

Tabel 5. Persentase Peserta Didik Tiap Skor pada Kategori Pengetahuan Posedural

\begin{tabular}{|c|c|c|c|c|c|c|}
\hline \multirow{3}{*}{ No. Soal } & \multicolumn{6}{|c|}{ Skor } \\
\hline & \multicolumn{2}{|c|}{0} & \multicolumn{2}{|c|}{1} & \multicolumn{2}{|c|}{2} \\
\hline & $\sum$ & $\%$ & $\sum$ & $\%$ & $\sum$ & $\%$ \\
\hline 1 & 7 & $22 \%$ & 16 & $50 \%$ & 9 & $28 \%$ \\
\hline 2 & 13 & $41 \%$ & 18 & $56 \%$ & 1 & $3 \%$ \\
\hline 3 & 14 & $44 \%$ & 17 & $53 \%$ & 1 & $3 \%$ \\
\hline 4 & 11 & $34 \%$ & 20 & $63 \%$ & 1 & $3 \%$ \\
\hline 5 & 14 & $44 \%$ & 16 & $50 \%$ & 2 & $6 \%$ \\
\hline 6 & 4 & $13 \%$ & 14 & $44 \%$ & 14 & $44 \%$ \\
\hline 7 & 8 & $25 \%$ & 17 & $53 \%$ & 7 & $22 \%$ \\
\hline 8 & 11 & $34 \%$ & 17 & $53 \%$ & 4 & $13 \%$ \\
\hline 9 & 11 & $34 \%$ & 17 & $53 \%$ & 4 & $13 \%$ \\
\hline 10 & 14 & $44 \%$ & 18 & $56 \%$ & 0 & $0 \%$ \\
\hline 11 & 31 & $97 \%$ & 1 & $3 \%$ & 0 & $0 \%$ \\
\hline 12 & 10 & $31 \%$ & 14 & $44 \%$ & 8 & $25 \%$ \\
\hline Rata-rata & 12 & $39 \%$ & 15 & $48 \%$ & 4 & $13 \%$ \\
\hline
\end{tabular}

Soal terkait prinsip kerja larutan penyangga, sebagian besar peserta didik memperoleh skor 1 . Peserta didik dengan skor 1, menunjukkan bahwa sebenarnya peserta didik sudah memahami maksud tugas tetapi gagasan yang dituliskan tidak spesifik dan tidak berhubungan dengan informasi yang diberikan. Misalnya, peserta didik menjawab apabila komponen di sebelah kiri kesetimbangan larutan penyangga dikurangi, kesetimbangan akan bergeser kekiri. Peserta didik tidak menjelaskan lebih lanjut kejadian setelah bergesernya kesetimbangan hingga proses pertahanan $\mathrm{pH}$ larutan. Contoh jawaban peserta didik dengan skor 0 (tidak menjawab atau menyebutkan strategi yang tidak sesuai dengan pertanyaan) disajikan berikut ini.

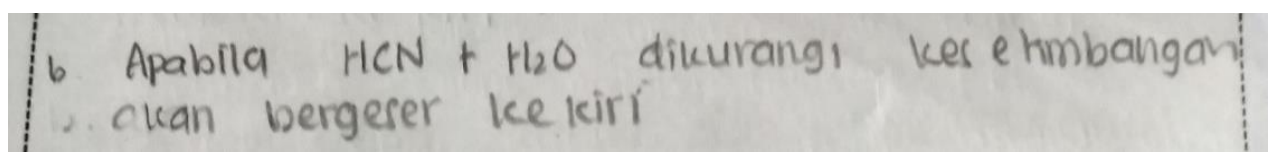

Gambar 3. Contoh jawaban peserta didik dengan skor 0

Sebenarnya jawaban tersebut sudah mengarah pada jawaban yang benar, namun belum disertai penjelasan terhadap jawaban yang diberikan, yaitu mengapa kesetimbangan bergeser ke kiri.

Soal terkait komponen penyusun larutan penyangga, sebagian besar peserta didik memperoleh skor 1. Tahapan yang diberikan tidak disertai dengan perhitungan yang membuktikan bahwa pasangan larutan tersebut merupakan pasangan larutan penyangga atau bukan. Tahapan seperti menentukan 
ciri-ciri komponen penyusun larutan yang mampu membentuk larutan penyangga belum dituliskan dalam penjelasan peserta didik.

Soal terkait klasifikasi jenis larutan penyangga asam, sebagian besar peserta didik memperoleh skor 1. Peserta didik menjawab dengan cara menulis satu per satu larutan dari pilihan jawaban lalu disesuaikan dengan ciri-ciri larutan." Gagasan yang dituliskan tersebut kurang spesifik sehingga memperoleh skor 1 .

Soal terkait perhitungan $\mathrm{pH}$ penyangga asam, sebagian besar peserta didik memperoleh skor 1 . Peserta didik menuliskan "Menentukan dan menulis persamaan reaksi, kemudian menghitung $\left[\mathrm{H}^{+}\right]$, kemudian menghitung $\mathrm{pH}$ larutan penyangga tersebut", peserta didik tidak menjabarkan bagaimana perhitungan dilakukan. Soal terkait perhitungan $\mathrm{pH}$ larutan penyangga basa, sebagian besar peserta didik memperoleh skor 1. Peserta didik dengan skor 1, nampak memahami maksud tugas tetapi menuliskan gagasan yang tidak spesifik dan tidak berhubungan dengan informasi yang diberikan. Tidak ada peserta idik yang menjawab, "Menghitung jumlah mol masing-masing larutan, menentukan pasangan larutan yang mungkin membentuk larutan penyangga, kemudian menghitung $\mathrm{pH}$ larutan, dan mencocokkannya dengan jawaban yang telah disediakan.”

Soal terkait perhitungan $\mathrm{pH}$ larutan penyangga setelah dilakukan penambahan sedikit asam kuat atau basa kuat atau dilakukan sedikit pengenceran, sebagian besar peserta didik memperoleh skor 1. Peserta didik menyebutkan strategi dengan tepat, tetapi sebagian besar peserta didik kurang tepat menghitung konsentrasi setelah pengenceran. Peserta didik tidak menggunakan volume akhir larutan setelah ditambahkan aquades, tetapi mereka menggunakan volume awal larutan untuk menghitung $\left[\mathrm{H}^{+}\right]$.

Soal terkait peran larutan penyangga dalam tubuh makhluk hidup. Peserta didik dengan skor 0 tidak menjawab atau tidak mejelaskan strategi yang sesuai dengan pertanyaan. Banyak peserta didik yang tidak memberikan jawaban pada soal ini. Tahapan penyelesaian soal seperti mencari opsi yang mengandung salah satu dari tiga larutan penyagga dalam air ludah kemudian mencari opsi yang merupakan reaksi kesetimbangan yang terjadi jika larutan penyangga dalam ludah ditambah asam kuat, tidak muncul dalam jawaban.

Soal terkait perhitungan pembuatan larutan penyangga jika harga $\mathrm{pH}$ larutan diketahui, disajikan pada soal nomor 9. Sebagian besar peserta didik memperoleh skor 1. Peserta didik tidak menjabarkan perhitungan yang dilakukan, peserta didik hanya menyebutkan langkah, seperti menghitung jumlah mol.

Berdasarkan penjabaran di atas, pengetahuan prosedural peserta didik tergolong sedang. Dapat dikatakan peserta didik Kelas XI SMA nampak memahami maksud tugas, tetapi peserta didik membuat gagasan yang tidak spesifik dan tidak berhubungan dengan informasi yang diberikan atau pertanyaan yang diajukan. Peserta didik belum mampu menjabarkan strategi jika berhubungan dengan prinsip kerja larutan penyangga, prinsip kerja larutan penyangga dalam tubuh atau komponen yang ada dalam larutan penyangga. Peserta didik mampu menentukan rumus yang akan digunakan namun, belum mampu memanfaatkan informasi yang tersedia pada soal. Hal ini diduga disebabkan karena pengetahuan dasar yang kurang dikuasai peserta didik. Sebagaimana penelitian yang dilakukan Hailikari, Katajavouri, Ylanne, dan Lindblom (2008), yang menyatakan bahwa pengetahuan dasar dari materi sebelumnya sangat mempengaruhi pengetahuan prosedural peserta didik.

\section{Pengetahuan Kondisional}

Data pengetahuan kondisional peserta didik pada materi larutan penyangga, diperoleh dari hasil tes pengetahuan metakognitif bagian pengetahuan kondisional. Persentase peserta didik tiap skor dapat dilihat pada Tabel 6 . 
Berdasarkan persentase rata-rata perolehan skor peserta didik, tingkat pengetahuan prosedural peserta didik sebanyak 91\% berada ditingkat rendah, 4\% berada ditingkat sedang dan 5\% berada ditingkat tinggi. Sebagian besar peserta didik memiliki pengetahuan deklaratif ditingkat rendah. Tingkat pengetahuan kondisional sebagian besar peserta didik berada pada tingkat rendah. Dapat diartikan bahwa, peserta didik belum mampu menjelaskan kapan dan mengapa menggunakan strategi ataupun konsep yang telah ditulis, untuk menyelesaikan masalah.

Soal terkait prinsip larutan penyangga (soal nomor 1), cukup banyak (53\%) peserta didik memperoleh skor 0. Sebagian besar peserta didik dengan skor 0, tidak menjawab pertanyaan. Peserta didik dengan skor 1, menjabarkan strategi (memberikan daftar) strategi secara umum untuk menyelesaikan masalah, tetapi tidak menjelaskan kapan dan mengapa strategi tersebut digunakan. Peserta didik yang menjawab dengan benar (34\%) dapat mendeskripsikan prinsip kerja larutan penyangga. Contoh jawaban peserta didik yang memperoleh skor 2 adalah sebagai berikut.

Tabel 6. Persentase Peserta Didik Tiap Skor pada Kategori Pengetahuan Kondisonal

\begin{tabular}{|c|c|c|c|c|c|c|}
\hline \multirow{3}{*}{ No. Soal } & \multicolumn{6}{|c|}{ Skor } \\
\hline & \multicolumn{2}{|c|}{0} & \multicolumn{2}{|c|}{1} & \multicolumn{2}{|c|}{2} \\
\hline & $\sum$ & $\%$ & $\sum$ & $\%$ & $\sum$ & $\%$ \\
\hline 1 & 17 & $53 \%$ & 4 & $13 \%$ & 11 & $34 \%$ \\
\hline 2 & 31 & $97 \%$ & 1 & $3 \%$ & 0 & $0 \%$ \\
\hline 3 & 29 & $91 \%$ & 2 & $6 \%$ & 1 & $3 \%$ \\
\hline 4 & 29 & $91 \%$ & 2 & $6 \%$ & 1 & $3 \%$ \\
\hline 5 & 29 & $91 \%$ & 2 & $6 \%$ & 1 & $3 \%$ \\
\hline 6 & 26 & $81 \%$ & 5 & $16 \%$ & 1 & $3 \%$ \\
\hline 7 & 30 & $94 \%$ & 1 & $3 \%$ & 1 & $3 \%$ \\
\hline 8 & 31 & $97 \%$ & 0 & $0 \%$ & 1 & $3 \%$ \\
\hline 9 & 31 & $97 \%$ & 0 & $0 \%$ & 1 & $3 \%$ \\
\hline 10 & 32 & $100 \%$ & 0 & $0 \%$ & 0 & $0 \%$ \\
\hline 11 & 32 & $100 \%$ & 0 & $0 \%$ & 0 & $0 \%$ \\
\hline 12 & 32 & $100 \%$ & 0 & $0 \%$ & 0 & $0 \%$ \\
\hline Rata-rata & 29 & $91 \%$ & 1 & $4 \%$ & 2 & $5 \%$ \\
\hline
\end{tabular}

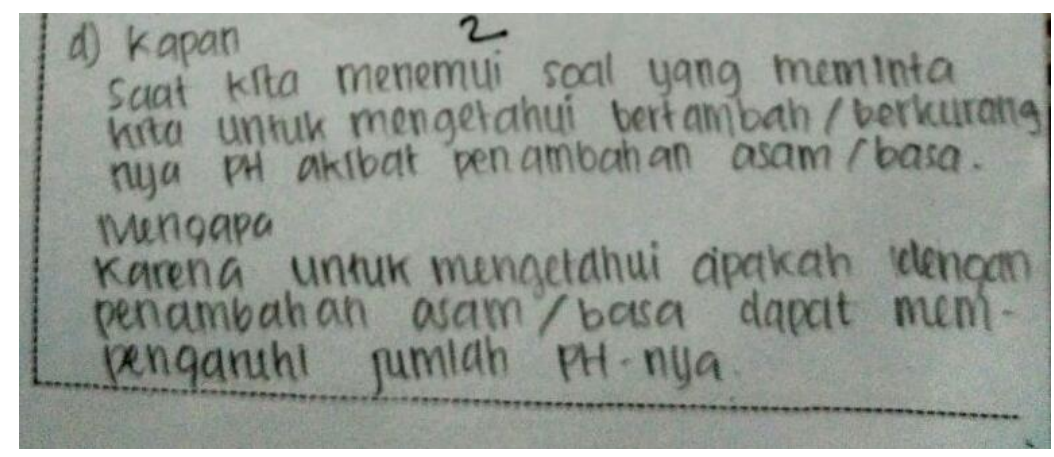

Gambar 4. Contoh jawaban peserta didik yang memperoleh skor 2

Soal terkait komponen penyusun larutan penyangga, sebagian besar peserta didik memperoleh skor 0 . Sebagian peserta didik dengan skor 0 menjawab, "karena hanya strategi itu yang saya pahami. Soal terkait klasifikasi jenis larutan penyangga, sebagian besar peserta didik memperoleh skor 0 . Peserta didik dengan skor 0 , tidak menjelaskan kapan dan mengapa menggunakan strategi tersebut untuk menyelesaikan masalah. Seperti ketika melihat soal serupa. 
Soal terkait perhitungan $\mathrm{pH}$ penyangga asam, sebagian besar peserta didik memperoleh skor 0 . Peserta didik dengan skor 0 , tidak menjelaskan kapan dan mengapa menggunakan strategi tersebut untuk menyelesaikan masalah. Soal terkait perhitungan $\mathrm{pH}$ penyangga basa, sebagian besar peserta didik memperoleh skor 0. Sebagian besar peserta didik menjawab "Setiap menemui soal seperti itu", sehingga memperoleh skor 0 . Pada soal nomor 9, perhitungan $\mathrm{pH}$ juga dilakukan namun, $\mathrm{pH}$ larutan penyangga setelah penambahan sejumlah asam kuat. Sebagian peserta didik menjawab "Jika terdapat soal sejenis", sehingga memperoleh skor 0 . Soal nomor 10, menanyakan pH larutan penyangga setelah penambahan aquades. Seluruh peserta didik memperoleh skor 0. Begitu pula soal nomor 11 yang menanyakan tentang reaksi kesetimbangan pada tubuh, dan soal nomor 12 yang menanyakan pembuatan larutan penyangga jika diketahui $\mathrm{pH}$ larutan tersebut. Sejumlah 32 peserta didik memperoleh skor 0 . Sebagian peserta didik tidak menjawab dan sebagian yang lain menjawab "Setiap menemui soal seperti itu".

Berdasarkan uraian di atas dapat dikatakan bahwa pengetahuan kondisonal peserta didik tergolong rendah. Dapat dikatakan sebagian besar peserta didik Kelas XI SMA tidak menjelaskan kapan dan mengapa menggunakan strategi yang dituliskan sebelumnya untuk menyelesaikan masalah. Mayoritas peserta didik memberikan pernyataan tidak relevan. Menurut Lukum (2015), salah satu penyebab rendahnya pengetahuan kondisional adalah, kebiasaan menghafal tanpa mengetahui makna, dan kegiatan verifikasi. Dalam kegiatan verifikasi, pendidik menyampaikan materi, kemudian peserta didik memverifikasi kebenaran materi tersebut dengan praktikum atau analisis data.

\section{Hubungan Pengetahuan Metakogitif dengan Hasil Belajar Peserta Didik}

Berdasarkan hasil analisis korelasi diketahui bahwa terdapat hubungan antara pengetahuan metakognitif dengan hasil belajar $(r=0,44$; thitung $=6,86>$ ttabel $=0,195)$ dengan kualitas sedang. Secara umum dapat dikatakan bahwa peserta didik yang memiliki pengetahuan metakognitif yang tinggi juga menunjukkan hasil belajar yang tinggi pula. Hasil korelasi yang sedang menunjukkan bahwa tidak seluruh hasil belajar peserta didik dapat diprediksikan dengan menggunakan pengetahuan metakognitif. Artinya, masih ada beberapa peserta didik dengan hasil belajar tinggi, tetapi memiliki pengetahuan metakognitif yang rendah. Menurut Tanner (2012), perbedaan ini dapat disebabkan karena peserta didik memiliki kemampuan yang berbeda dalam menggunakan pengetahuan metakognitifnya. Peserta didik mampu menjawab pertanyaan (memiliki hasil belajar yang tinggi), namun memiliki pengetahuan metakognitif yang rendah.

Pengetahuan deklaratif dan hasil belajar memperlihatkan hubungan positif $(\mathrm{r}=0,32$; thitung $=5,34$ $>$ ttabel $=0,195)$. Pengetahuan deklaratif berhubungan dengan konsep atau pengetahuan yang dibutuhkan peserta didik dalam menyelesaikan masalah yang diberikan (Rompayom et al, 2010). Peserta didik dengan pengetahuan awal yang baik dapat memiliki hasil belajar yang baik pula.

Pengetahuan prosedural dengan hasil belajar peserta didik menunjukkan hubungan positif $(r=0,44$; thitung $=7,45>$ ttabel=0,195). Rompayom (2010) mengungkapkan bahwa pengetahuan prosedural sangat berhubungan dengan pengetahuan untuk memecahkan masalah. Peserta didik yang memiliki kemampuan memecahkan masalah yang tinggi juga memiliki hasil belajar yang tinggi pula.

Hubungan antara pengetahuan kondisional dengan hasil belajar peserta didik menunjukkan hubungan kuat $(\mathrm{r}=0,66$; thitung $=8,97>$ ttabel=0,195). Hal ini menunjukkan bahwa peserta didik dengan hasil belajar tinggi juga memiliki pengetahuan kondisional tinggi. Atau semakin rendah hasil belajar peserta didik semakin rendah pengetahuan kondisionalnya. 


\section{Hubungan antara Metacognitive Awareness Inventory dan Hasil Belajar}

Hasil analisis menunjukkan bahwa hasil belajar dengan pengetahuan metakognitif yang diukur dengan MAI memiliki hubungan negatif yang sangat lemah $(\mathrm{r}=-0,13)$. Hasil yang serupa juga diperoleh tentang hubungan antara hasil belajar dengan pengetahuan deklaratif yang diukur dengan MAI $(r=-0,19)$ dan hubungan antara hasil belajar dengan pengetahuan prosedural yang diukur dengan MAI $(r=-0,11)$. Hubungan antara pengetahuan kondisional hasil MAI dengan hasil belajar memberikan hubungan positif $(\mathrm{r}=0,22)$, namun hubungan ini berada di tingkatan rendah (tidak signifikan). Shabanivarki dalam Hoseinzadeh et al (2013), mengungkapkan bahwa pola pikir seseorang, mempengaruhi bagaimana mereka menyelesaikan masalah yang dihadapi. Hasil penelitian Otaya (2015) menunjukkan sebagian peserta didik berusaha untuk menilai dirinya sendiri secara objektif, tetapi kenyataannya sebagian besar dari peserta didik cenderung menilai diri mereka secara positif (lebih baik) untuk menunjukkan optimisme positif.

Kuadrat koefisien korelasi dari hasil belajar dengan pengetahuan metakognitif (instrumen Rompayom) lebih besar dibandingkan dengan kuadrat koefisien korelasi hubungan hasil belajar dengan pengetahuan metakognitif MAI (Tabel 7). Dengan demikian dapat dikatakan bahwa tes pengetahuan metakognitif yang diadaptasi Rompayom (2010) lebih mampu menunjukkan pengetahuan metakognitif peserta didik dibandingkan instrument MAI.

Tabel 7. Perbandingan Hasil Analisis Data

\begin{tabular}{|c|c|c|c|c|c|}
\hline Variabel yang Diuji & $\begin{array}{l}\text { Jenis Uji } \\
\text { Korelasi }\end{array}$ & $\begin{array}{l}\text { Nilai } \\
\text { Koefisien } \\
\text { Korelasi } \\
\text { (r) }\end{array}$ & $\left(\mathrm{r}^{2}\right)$ & thitung $_{\text {hith }}$ & Hasil tes signifikansi \\
\hline $\begin{array}{l}\text { Pengetahuan } \\
\text { Metakognitif dengan } \\
\text { Hasil Belajar }\end{array}$ & $\begin{array}{c}\text { Korelasi } \\
\text { Biserial }\end{array}$ & 0,44 & 0,195 & 6,864 & Signifikan \\
\hline $\begin{array}{l}\text { Pengetahuan } \\
\text { Metakognitif (MAI) } \\
\text { dengan Hasil Belajar }\end{array}$ & $\begin{array}{l}\text { Korelasi } \\
\text { Point } \\
\text { Biserial } \\
\end{array}$ & $-0,13$ & 0,016 & $-0,709$ & Tidak Signifikan \\
\hline
\end{tabular}

Berdasarkan hasil analisis signifikansi, hubungan hasil belajar dengan pengetahuan metakognitif hasil tes yang diadaptasi berdasarkan Rompayom, menunjukkan hasil yang signifikan, sehingga dapat dikatakan hasil belajar dapat dijelaskan dengan pengetahuan metakognitif hasil tes. Sedangkan hasil analisis signifikansi, hubungan antara hasil belajar dengan pengetahuan metakognitif hasil MAI, menunjukkan hasil tidak signifikan, sehingga dapat dikatakan hasil belajar tidak dapat dijelaskan dengan pengetahuan metakognitif hasil MAI. Dapat dikatakan, bahwa pengetahuan metakognitif hasil tes, lebih mampu menunjukkan pengetahuan metakognitif peserta didik dibandingkan instrumen MAI.

Menurut Zaidner dalam Susongko (2010), pada bentuk tes uraian, dibutuhkan kemampuan berpikir yang lebih tinggi dalam mengorganisasi jawaban, mengingat materi, dan kemampuan menulis dengan baik. Keadaan tersebut berbeda dengan tes pilihan, dimana peserta didik hanya memilih pilihan (opsi) yang tersedia. Jika peserta didik menjawab benar pada item yang sama pada tipe tes pilihan ganda, sangat sukar disimpulkan bahwa pilihannya didasarkan pada hasil berfikir yang kompleks.

Instrumen angket seperti MAI cenderung memiliki kelemahan dalam hal objektivitas. Hasil penelitian Otaya (2015) menunjukkan, sebagian peserta didik berusaha untuk menilai dirinya sendiri secara objektif, tetapi kenyataannya sebagian besar dari peserta didik cenderung menilai diri mereka secara positif (lebih baik) untuk menunjukkan optimisme positif. Dapat dikatakan bahwa instrumen angket belum tentu bisa mengungkapkan bagaimana pengetahuan metakognitif peserta didik sebenarnya. 


\section{KESIMPULAN}

Mayoritas peserta didik memiliki pengetahuan deklaratif dan prosedural tingkat sedang, sedangkan pengetahuan kondisional tingkat rendah. Ada hubungan antara pengetahuan metakognitif dengan hasil belajar ( $\mathrm{r}=0,44$; sedang). Ada hubungan antara pengetahuan deklaratif, prosedural, dan kondisional dengan hasil belajar dengan nilai $\mathrm{r}$ berturut-turut ( $\mathrm{r}=0,32$; rendah); $(\mathrm{r}=0,44$; sedang); dan ( $r=0,66$; kuat). Tidak ada hubungan antara kemampuan metakognitif dari MAI dan hasil belajar $(\mathrm{r}=-0,13)$. Tidak ada hubungan antara pengetahuan deklaratif, prosedural dan kondisional dari MAI dan hasil belajar dengan nilai korelasi berturut-turut $-0,18 ;-0,11$; dan 0,22 . Pengetahuan metakognitif hasil tes yang diadaptasi dari Rompayom (2010), lebih mampu menunjukkan pengetahuan metakognitif peserta didik dibandingkan instrumen MAI.

Guru hendaknya memperhatikan pengetahuan metakognitif peserta didiknya dalam memilih strategi/model pembelajaran, agar dapat membelajarkan materi kimia dengan baik dan bermakna sehingga pemahaman peserta didik lebih baik.

Dalam membelajarkan kimia, diharapkan guru menerapkan strategi pembelajaran yang memfasilitasi peningkatan pengetahuan metakognitif peserta didik. Strategi ini dapat terdiri dari perencanaan atau pengorganisasian sebelum pembelajaran, memonitor atau mengidentifikasi masalah, mengevaluasi dan mengatur pembelajaran diri sendiri yang berupa bagaimana belajar dengan lebih baik. Pengetahuan peserta didik dalam menguasai konsep, strategi yang digunakan, dan pengetahuan terkait kapan dan mengapa menggunakan pengetahuan atau strategi tersebut untuk memecahkan masalah diharapkan dapat meningkat melalui pembelajaran. Pada panelitian ini digunakan sampel (subjek) yang kecil, sehingga hasil yang diperoleh perlu diverifikasi lagi dengan penelitian sejenis yang menggunakan sampel yang lebih besar.

\section{DAFTAR RUJUKAN}

Amborse, S. A. (2010). How learning works. New York: Jossey Bass.

Cook, E., Kennedy, E., McGuire, S, Y. (2013). Effect of teaching metacognitive learning strategies on performance in general chemistry courses. Journal Chemistry Education: American Chemical Society and Division of Chemical Education, 90, 961-967. Dari: https://pubs.acs.org/doi/abs/ 10.1021ᄀ/ed300686h.

Egan, E. (2014). Getting Faculty to Promote Metacognitive in Students. Dari: http://cese.science.psu.edu/files/PromoteMetacognition.pdf.

Flavell, J. H. (1979). Metacognition and Cognitive Monitoring: A New Area of Cognitive-Developmental Inquiry. American Psychologist, 34 (10), 906-911. Dari https://www.researchgate.net/publication/232599909_Metacognition_and_Cognitive_Monitoring_A _New_Area_of_CognitiveDevelopmental_Inquiry.

Hailikari, T., Katajavouri, N., Ylanne, S, L. (2008). The Relevance of Prior Knowledge in Learning and Instructional Design. American Journal of Pharmacetical Education, 72(5), 1-8. Dari: https://www.ncbi.nlm.nih.gov/pmc/articles/PMC2630138/pdf/ajpe 113.pdf.

Hoseinzadeh, D., Shoghi, B. (2013). The Role of Metacognition Knowledge Component in Achivement of High School Male Students. Procedia. 84. 1031-1035. dari: www.sciencedirect.com.

Isnaini, Masriani, Sartika, R.P. (2015). Pemahaman Konsep Materi Larutan Penyangga Menggunakan TwoTier Multiple Choice Diagnostic Instrument di SMA. Program Studi Pendidikan Kimia FKIP UNTAN Pontianak.

Jaleel, S. (2016). A Study on the Metacognitive Awareness of Secondary School Students.Universal Journal of Educational Research, 4(1), 165-172. 
Josep, J. (2008). Types of Knowledge and Their Relation to Problem Solving in Science: Direction for $\begin{array}{llll}\text { Practice. Educational Science Journal. (6). 105-112. Dari: } & \end{array}$ https://www.reaserchgate.net/publication/26572636.

Lukum, A., Laliyo, L. A. R., Sukanto, K. (2015). Metakognisi Mahasiswa dalam Pembelajaran Kesetimbangan Kimia. Jurnal Ilmu Pendidikan,21(1), 9-18. Dari: http://repository.ung.ac.id/get/karyailmiah/1456/Astin-Lukum-Meta kognisi-Mahasis-wa-DalamPembelajaran-Kesetimbangan-Kimia.pdf.

Marsita, R, A. (2010). Analisis Kesulitan Belajar Kimia Siswa SMA dalam Memahami Materi Larutan Penyangga dengan Menggunakan Two-Tier Mutiple Choice Diagnostic Instrument. Jurnal Inovasi Pendidikan Kimia, 4(1), 512-520. Dari: file:///D:/Downloads/1308-3023-1-PB.pdf.

Otaya, L.G. 2015. Urgensi Sikap Mahasiswa Menilai Kemampuan Diri dalam Belajar melalui Asesmen Diri (Self-Assessment). Jurnal Manajemen Pendidikan Islam. 3(1). Tersedia pada http://journal.iaingorontalo.ac.id/index.php/tjmpi. 26 Juli 2016.

Parastuti, W.I., Suharti, Ibnu, S. (2016). Miskonsepsi Siswa pada Materi Larutan Buffer. Jurnal Pendidikan. 1. (12). $2307-2313$.

Rompayom, P., Tambunchong, C., Wongyounoi, S. \& Dechsri, P. (2010). The Development of Metacognitive Inventory to Measure Students' Metacog nitive Knowledge Related to Chemical Bonding Conceptions. Internation $\neg \neg$ al Association for Educational Assesment (IAEA). Dari http://www.iaea. info/documents/paper_4d52b63.pdf.

Sesen, B. A \& Tarhan, L. (2011). Active-Learning Versus Teacher Centered Instruction For Learning Acids and Bases. Research in Science \& Technological Education, 29 (2), 205-226. Dari: https://www. Tandfonline .com /doi/abs/10.1080/02635143.2011.581630.

Sirhan, G. (2007). Learning Difficulties in Chemistry: An Overview. Journal of Turkish Science Education, 4(2), 2-20. Dari: https://www.researchgate.net /publication/26474914_Learning_Difficulties_in_Chemistry_anOverview.

Susangko, P. (2010). Perbandingan Keefektifan Bentuk Tes Uraian dan Testlet dengan Penerapan Graded Response Model (GRM). Jurnal Matematika FKIP UPS Tegal, 2, 269-288.

Tanner, Kimberly. 2012. Promoting Student Metacognition. CBE: Life Sciences Education, 11, 113-120. Dari: https://www.ncbi.nlm.nih.gov/pmc/articles /PMC 3366894/pdf/113.pdf.

Ulva,Y.I., Santosa, Parlan. (2016). Identifikasi Tingkat Pemahaman Konsep Larutan Penyangga Aspek Makroskopik, Submikroskopik, dan Simbolik Pada Siswa Kelas XI IPA SMAN 3 Malang Tahun Ajaran 2013/ 2014. Jurnal Pembelajaran Kimia (J-PEK) 1(2), 69-75. 